Check for updates

Portsmouth Hospitals NHS Trust

drparthakar@gmail.com Follow Partha on Twitter: @parthaskar Cite this as: BMJ 2022;376:016 http://dx.doi.org/10.1136/bmj.016 Published: 11 January 2022

\title{
THE BOTTOM LINE
}

\section{Partha Kar: Let's plan ahead to support our GPs}

\section{Partha Kar consultant in diabetes and endocrinology}

"It really hurts," he said, sipping his beer in his usual languid style. "All those years of staying on, not giving enough time to family, the late hours-then to be told this? It doesn't feel worth it." For the sake of anonymity, let's call him Peter Parker. He's a GP, and his long day had just ended with an abusive patient telling him that GPs weren't working hard enough or giving patients enough time.

I've known Peter for more than a decade. I've seen him progress in his career and never heard him complain. He's incredibly relaxed, a fabulous friend, and a wonderful family man. He's at the extreme edge of my barometer on how the NHS workforce is holding up. I've always thought, if Peter ever felt like giving up, we'd be well and truly in turmoil.

And then he said it: “It doesn't feel worth it.” For once, I had no clever banter or sharp sarcasm to offer. Into those words was etched the pain of a professional, far from his home country, who had devoted so much, at the expense of so much personal stuff, to care for others. How did we get here?

We live in a country purported to have one of the strongest vaccine programmes, and we've pinned our faith on boosters. Yet we've had to halt a huge amount of routine care to deliver them. Things that were already delayed or halted are paused further. And mixed messages have made many wonder about the healthcare system's role.

Shrill announcements of vaccine success, based on numbers, mask the suspension and reduction of much routine care. Understandable public frustration is often directed at frontline workers, whether in primary care or emergency departments. The challenge ahead is not just how we catch up, but how we do so when many like Peter are saying, "I'm done.” You can only make so many calls to workers' altruism, especially when sections of the media use them as a punchbag.

So, what can we do? For starters, let's prepare for the next possible variant or dosing requirements. If it's not needed, great-but at least we can plan ahead. A vaccine delivery workforce could mean not having to depend (again) on primary care or suspend most other work. Beyond the media visibility around emergency care targets and waiting lists for surgery, mental health and long term conditions are poor cousins, while being the biggest contributors to healthcare costs in the NHS.

We need a strategy so that we're not caught on the hop again in 2022. If we believe that "vaccine holds the key," we also need to factor in that some people won't take it, whatever the restrictions or rewards.
We need to estimate what level of admission or intensive care support they need and plan for it.

The next step has to be a move away from jingoistic nationalism. I appreciate that it's something most countries struggle with in today's world. Yet the virus couldn't care less about how great your country is. We have a variant in play, as many had predicted from the vaccine apartheid. If you don't look after the poor countries, the rich ones eventually get bitten, and their economies are hit.

Finally, we need a genuine effort to help primary care deliver, especially for long term conditions. Without this, no amount of clever digital innovation or system working can hold the NHS together. If even Peter decides that "it's not worth it," there's no other option on the table bar investing in primary care. And we should strain every sinew to do so-not more money for the NHS with a small percentage given to primary care, but a sustained focus on increasing its funding. If elective care needs a recovery fund, so do long term conditions.

Only so many times can a workforce buckle up and ride again. However, nothing is ever completely lost, and the challenges currently facing the NHS still give us an opportunity to do some things better. With planning, nationally and internationally, we can get to a better place. We must plan better to ensure that Peter doesn't lose his zeal, his passion, or simply his love to help patients do better. We all owe him that.

Competing interests: www.bmj.com/about-bmj/freelance-contributors.

Provenance and peer review: Commissioned; not externally peer reviewed. 